\title{
Coronary vasodilation and positive inotropism by urocortin in the isolated rat heart
}

\author{
K Terui, A Higashiyama ${ }^{1}$, N Horiba, K-I Furukawa ${ }^{1}$, S Motomura ${ }^{1}$ \\ and T Suda \\ Third Department of Medicine, Hirosaki University School of Medicine, Hirosaki 036-8563, Japan \\ ${ }^{1}$ Department of Pharmacology, Hirosaki University School of Medicine, Hirosaki 036-8563, Japan \\ (Requests for offprints should be addressed to K Terui, Third Department of Medicine, Hirosaki University School of Medicine, 5 Zaifu-Cho, Hirosaki, \\ Aomori 036-8563, Japan; Email: teru-ken@wb3.so-net.ne.jp)
}

\begin{abstract}
Corticotropin-releasing factor (CRF) has a coronary vasodilator effect and a positive inotropic effect on the isolated rat heart. Recently, expression of CRF receptor type 2 (CRF-R2) has been demonstrated in the heart. In addition, urocortin $\left(\mathrm{Ucn}_{\mathrm{cn}}\right)$, a new member of the CRF family, has been reported to have much greater affinity for CRF-R2 than CRF. It is suggested that the cardiac effects of $U \mathrm{cn}$ may be more potent than those of CRF.

We compared the effect of Ucn with that of CRF on isolated rat heart. The effects of $U_{c n}$ were then analyzed to determine whether these effects were mediated by CRF receptors and/or any other mediators under the
\end{abstract}

following conditions: perfusion buffer containing (1) $\alpha$-helical CRF 9-41, (2) indomethacin, (3) $\mathrm{N}^{\mathrm{G}}$-nitro-Larginine methylester and (4) propranolol. Ucn exhibited a greater effect with a longer duration of action than CRF. Indomethacin significantly attenuated the vasodilator effects of $\mathrm{Ucn}_{\mathrm{cn}}(P<0 \cdot 05)$. CRF receptor antagonist diminished both coronary vasodilation and the positive inotropic effects of $U \mathrm{cn}(P<0 \cdot 05)$.

These results suggest that the cardiac effects of $U_{c n}$ may be mediated by a CRF receptor, and prostaglandins may be involved in the vasodilator effect.

Journal of Endocrinology (2001) 169, 177-183

\section{Introduction}

Corticotropin-releasing factor (CRF), a 41 amino acid peptide, is a primary factor contributing to stress response in mammals (Vale et al. 1981, 1983). This peptide regulates the hypothalamic-pituitary-adrenal axis and exerts diverse effects on the central nervous, reproductive, immune and cardiovascular systems (Vale et al. 1983, Smith et al. 1989).

The effects of CRF on the cardiovascular system have been extensively studied. It has been shown to exhibit different cardiovascular effects in vivo when administered intravenously compared with those when administered into the cerebral ventricles. Heart rate, cardiac output and mean arterial pressure increased with intracerebroventricular administration of CRF (Fisher et al. 1983, Overton et al. 1990, Overton \& Fisher 1991). In contrast, intravenous administration of CRF decreased mean arterial pressure (Fisher et al. 1982, Overton \& Fisher 1991). In 1993, Grunt et al. showed that in isolated rat hearts perfused with Krebs-Henseleit buffer (KHB) the peptide caused a positive inotropic effect and an increase in coronary flow (Grunt et al. 1993). These reports suggest the presence of specific CRF receptors in the cardiovascular system.

Recently, two subtypes of CRF receptor have been characterized and termed CRF receptor type 1 (CRF-R1) and CRF receptor type 2 (CRF-R2) (Chang et al. 1993, Potter et al. 1994, Wong et al. 1994, Kishimoto et al. 1995, Lovenberg et al. 1995b, Perrin et al. 1995, Stenzel et al. 1995, Kostich et al. 1998). It has been reported that CRF-R1 is expressed in brain and pituitary (Chang et al. 1993, Potter et al. 1994, Wong et al. 1994). However, CRF-R2 was expressed not only in the central nervous system (Lovenberg et al. 1995b, Kostich et al. 1998) but also in peripheral tissues, including the heart (Kishimoto et al. 1995, Lovenberg et al. 1995a, Perrin et al. 1995, Stenzel et al. 1995).

In 1995, Vaughan et al. cloned a new member of the mammalian CRF family named urocortin ( $\mathrm{Ucn})$, which is a 40 amino acid peptide cloned from the rat midbrain (Vaughan et al. 1995). Ucn is reported to bind and activate CRF receptors to a greater extent than CRF. In particular, Ucn has much greater affinity for CRF-R2. It is therefore suggested that Ucn may be a natural ligand for CRF-R2, and its cardiovascular effects might be more 
Table 1 Results are shown as mean concentrations ( \pm S.E.M.) in the hearts between $15 \mathrm{~s}$ of injection and maximum decrease ( \pm S.E.M.) in CPP with CRF and Ucn at $1 \mu \mathrm{g}(n=5)$, $3 \mu \mathrm{g}(n=5)$ and $10 \mu \mathrm{g}(n=5)$

\begin{tabular}{|c|c|c|c|c|}
\hline & \multicolumn{2}{|l|}{ CRF } & \multicolumn{2}{|l|}{ Ucn } \\
\hline & $\begin{array}{l}\text { Concentration } \\
(\mathrm{nM})\end{array}$ & $\begin{array}{l}\text { Decrease in CPP } \\
(\%)\end{array}$ & $\begin{array}{l}\text { Concentration } \\
(\mathrm{nM})\end{array}$ & $\begin{array}{l}\text { Decrease in CPP } \\
(\%)\end{array}$ \\
\hline \multicolumn{5}{|c|}{ Dose $(\mu \mathrm{g})$} \\
\hline 1 & $88 \cdot 0 \pm 5 \cdot 0$ & $4 \cdot 0 \pm 1 \cdot 4$ & $86 \cdot 3 \pm 7 \cdot 1$ & $4 \cdot 2 \pm 0.9$ \\
\hline 3 & $214 \cdot 2 \pm 8 \cdot 2$ & $12 \cdot 7 \pm 2 \cdot 2$ & $205 \cdot 9 \pm 10 \cdot 0$ & $27 \cdot 0 \pm 5 \cdot 0^{*}$ \\
\hline 10 & $689 \cdot 4 \pm 18 \cdot 4$ & $29 \cdot 8 \pm 1 \cdot 9$ & $660 \cdot 7 \pm 12 \cdot 6$ & $38 \cdot 8 \pm 3 \cdot 2^{*}$ \\
\hline
\end{tabular}

${ }^{*} P<0.05$ compared with CRF-treated hearts.

potent than those of CRF. Parkes et al. (1997) showed that Ucn produces long-lasting actions that increase coronary flow and enhance cardiac contractility in conscious sheep, but the effect of $U \mathrm{cn}$ in the isolated heart has not yet been confirmed.

The purpose of this study was to determine whether Ucn possesses positive inotropic and coronary vasodilator effects on isolated rat hearts, as does CRF, and to determine whether these effects of $U \mathrm{cn}$ are mediated by CRF receptors and/or any other mediators. The present study was therefore conducted to investigate the cardiovascular effects of Ucn and CRF on isolated rat heart preparations perfused with a constant coronary flow rate.

\section{Materials and Methods}

\section{Isolated rat heart preparation}

Male Sprague-Dawley rats (350-450 g) were anesthetized with sodium pentobarbital $(50 \mathrm{mg} / \mathrm{kg}$, i.p.). While maintaining artificial ventilation, the chest was opened at the median line of the sternum and the pericardium was opened widely. After administration of heparin (5000 $\mathrm{U} / \mathrm{kg}$, i.v.), both pulmonary hila and the superior vena cava were ligated simultaneously. A perfusion tube was immediately inserted into the ascending aorta to perfuse the coronary arteries with $\mathrm{KHB}$ (concentrations in mmol/l: $\mathrm{NaCl} 118, \mathrm{KCl} 4 \cdot 7, \mathrm{CaCl}_{2} 2 \cdot 5, \mathrm{MgSO}_{4} 1 \cdot 2$, $\mathrm{NaHCO}_{3} 25, \mathrm{KH}_{2} \mathrm{PO}_{4} 1 \cdot 2$, glucose $11 \cdot 7$, EDTA $0 \cdot 03$, ascorbic acid 0.06) equilibrated with $95 \% \mathrm{O}_{2}$ and $5 \% \mathrm{CO}_{2}$ $(\mathrm{pH} 7 \cdot 4)$ at a constant temperature $\left(37^{\circ} \mathrm{C}\right)$. Interruption of coronary perfusion lasted no longer than $20 \mathrm{~s}$. The inferior vena cava was then ligated and the heart was removed from the chest and suspended from the coronary perfusion tube. A small vent was inserted into the left ventricular apex to drain Thebesian outflow. A flexible tube was inserted into the right ventricle for coronary venous drainage. Coronary flow was measured by timed collections of coronary drainage into a $10 \mathrm{ml}$ glass pipette. A collapsed, thin, high-density polyethylene balloon was placed in the left ventricle through the mitral orifice. The balloon was connected to a pressure transducer and a $1 \mathrm{ml}$ graduated syringe. Pacing electrodes connected to an electronic stimulator were attached to the surface of the left ventricle. Coronary perfusion pressure was measured with a pressure transducer connected to a side arm of the coronary perfusion tube. Coronary flow rate was adjusted to obtain a perfusion pressure similar to the in situ blood pressure, and kept constant throughout the experiment. The heart was placed in a chamber with a heating jacket, and the temperature of the heart was maintained at $35-37^{\circ} \mathrm{C}$.

\section{Experimental protocol}

After coronary perfusion pressure (CPP), coronary flow (CF), and left ventricular pressure (LVP) were stabilized, either rat Ucn or human/rat CRF dissolved in $100 \mu \mathrm{l}$ saline was injected into the perfusion tube just above the heart as a bolus for about $15 \mathrm{~s}$. Recordings were made under the baseline condition and then repeated at 1-min intervals for $10 \mathrm{~min}$ after the injection of the peptide. The changes in the hemodynamic measurements are expressed by the percent changes from baseline. We examined the dose-related effects of 1,3 and $10 \mu \mathrm{g} U \mathrm{cn}$ or CRF in 15 hearts. Because the molecular weight of Ucn (4707) is very similar to that of CRF (4757), the injections of each amount of Ucn and CRF produced almost the same concentrations of the two peptides in the hearts within about $15 \mathrm{~s}$ of the injections. The concentrations were calculated by the coronary flow (Table 1). The selected dose of the peptides was based on the report of Grunt et al. (1993). The vasodilator effects of Ucn $(3 \mu \mathrm{g})$ were studied in separate hearts perfused with unchanged $\mathrm{KHB}, \mathrm{KHB}$ containing $\alpha$-helical CRF 9-41 (1 or $10 \mathrm{nM}$ ) which blocks CRF-R, KHB containing indomethacin $(30 \mu \mathrm{M})$ which inhibits cyclo-oxygenase or KHB containing $\mathrm{N}^{\mathrm{G}}$-nitro-L-arginine methylester (L-NAME) $(30 \mu \mathrm{M})$ which inhibits nitric oxide synthase.

The inotropic effect of Ucn $(10 \mu \mathrm{g})$ was also determined in separate hearts perfused with unchanged KHB, KHB 
Table 2 Means ( \pm S.E.M.) basal CF and CPP in hearts perfused with unchanged KHB $(n=34)$, KHB containing L-NAME $(30 \mu \mathrm{M}, n=5)$, indomethacin ( $30 \mu \mathrm{M}, n=9)$, propranolol ( $3 \mu \mathrm{M}, n=4)$, $\alpha$-helical CRF ( $1 \mathrm{nM}, n=5), \alpha$-helical CRF (10 nM, $n=5)$ or $\alpha$-helical CRF $(30 \mathrm{nM}, n=4)$

\begin{tabular}{llll} 
& $\begin{array}{l}\text { CF } \\
(\mathrm{ml} / \mathrm{min})\end{array}$ & & $\begin{array}{l}\text { CPP } \\
(\mathrm{mmHg})\end{array}$ \\
$\begin{array}{llc}\text { Unchanged KHB } \\
\text { L-NAME }\end{array}$ & $12 \cdot 1 \pm 0 \cdot 6$ & & $106 \cdot 0 \pm 1 \cdot 8$ \\
Indomethacin & $12 \cdot 4 \pm 2 \cdot 9$ & & $121 \cdot 2 \pm 1 \cdot 8^{*}$ \\
Propranolol & $10 \cdot 2 \pm 1 \cdot 3$ & & $97 \cdot 9 \pm 2 \cdot 5$ \\
$\alpha$-helical CRF (1 nM) & $13 \cdot 1 \pm 1 \cdot 5$ & & $95 \cdot 0 \pm 2 \cdot 6$ \\
$\alpha$-helical CRF (10 nM) & $12 \cdot 3 \pm 1 \cdot 1$ & & $94 \cdot 2 \pm 4 \cdot 1$ \\
$\alpha$-helical CRF (30 nM) & $11 \cdot 1 \pm 2 \cdot 2$ & \\
& & $96 \cdot 0 \pm 2 \cdot 1$ \\
\hline
\end{tabular}

${ }^{*} P<0 \cdot 05$ compared with hearts perfused with unchanged KHB.

containing $\alpha$-helical CRF 9-41 (30 nM), KHB containing propranolol $(3 \mu \mathrm{M})$, or $\mathrm{KHB}$ containing indomethacin $(30 \mu \mathrm{M})$.

\section{Statistical analysis}

The data were analyzed by a repeated measures design ANOVA, or by a one-way ANOVA. When the F test indicated a significant difference among the conditions, the Student-Newman-Keuls test was used to test the significance of difference between specific conditions. All data are presented as means \pm s.E.M. and $P<0.05$ was considered to indicate statistical significance.

\section{Results}

\section{Basal CPP and CF}

Table 2 summarizes the baseline of CPP and CF in hearts perfused under different conditions. L-NAME showed an increase of CPP compared with unchanged KHB.

\section{Effects on coronary vascular resistance}

Both Ucn and CRF decreased CPP at a constant flow rate, indicating that both induced coronary vasodilation. The decrease in CPP with CRF attained its maximum response at $1 \mathrm{~min}$ after injection, and CPP gradually returned to its initial level. Vasodilator response with Ucn culminated at 3-5 min after the injection and lasted for approximately $10 \mathrm{~min}$. Table 1 summarizes the maximum values of percent decrease in CPP with CRF and Ucn at each dose. Both peptides decreased CPP in a dosedependent manner. Ucn showed a significantly greater decrease in CPP than CRF at $3 \mu \mathrm{g}$ and $10 \mu \mathrm{g}(P<0 \cdot 05)$ by one-way ANOVA. A repeated measures ANOVA showed a significant difference of the vasodilator effects between CRF and Ucn at each dose $(P<0 \cdot 05)$ (Fig. 1).
Indomethacin significantly attenuated the vasodilator effects of Ucn $(P<0 \cdot 05)$, but L-NAME did not (Fig. 2).

\section{Effects on the increase in cardiac contractility}

Both Ucn and CRF increased LVP and rate of left ventricular pressure increase $(\mathrm{LVdP} / \mathrm{dt})$. We chose $10 \mu \mathrm{g}$ CRF or Ucn for the main experiments, because the positive inotropic effects with 1 or $3 \mu \mathrm{g}$ of both peptides were not potent enough to measure. LVP reached the maximum value at $1 \mathrm{~min}$ after injection with CRF, so did $\mathrm{LVdP} / \mathrm{dt}$. However, the positive inotropic effect had a shorter duration than the coronary vasodilator effect and it lasted no longer than $5 \mathrm{~min}$. With $\mathrm{Ucn}_{\mathrm{cn}}$, the peak LVP increased to its maximum value at 3 min after injection and gradually returned to the baseline level thereafter. The maximum increases in LVP were $11.7 \pm 1 \cdot 7 \%$ with $10 \mu \mathrm{g}$ $\mathrm{CRF}$ and $11 \cdot 6 \pm 2 \cdot 3 \%$ with $10 \mu \mathrm{g}$ Ucn. Peak changes in $\mathrm{LVdP} / \mathrm{dt}$ were $14.5 \pm 3 \cdot 0 \%$ with $10 \mu \mathrm{g} \mathrm{CRF}$ and $23 \cdot 3 \pm 5.9 \%$ with $10 \mu \mathrm{g}$ Ucn. There was a significant difference in the increase in cardiac contractility between CRF and Ucn at a dose of $10 \mu \mathrm{g}(P<0 \cdot 05)$ (Fig. 3).

Propranolol and indomethacin did not influence the positive inotropic effects of Ucn (Fig. 4).

\section{Effect of $a$-helical CRF 9-41}

Pretreatment with $\alpha$-helical CRF 9-41 diminished the $3 \mu \mathrm{g}$ Ucn-induced decrease in CPP (Fig. 5), as well as the $10 \mu \mathrm{g} \mathrm{Ucn}$-induced increase in LVP and $\mathrm{LVdP} / \mathrm{dt}$ $(P<0 \cdot 05)$ (Fig. 4).

\section{Discussion}

In this study, we have investigated the direct cardiovascular effects of Ucn and CRF in isolated rat hearts. The two peptides exerted a coronary vasodilator effect and positive inotropism. CPP showed the maximum decrease at $1 \mathrm{~min}$ after administration of CRF and then returned to the control level. Such a change in CPP was similar to CRF-induced increase in coronary flow (Grunt et al. 1993). However, Ucn-induced vasodilation attained its maximum response at 3-5 $\mathrm{min}$ after injection and plateaued thereafter. The maximum vasodilator responses from 3 and $10 \mu \mathrm{g} \mathrm{Ucn}$ were greater than those of CRF.

We also found that the increases in LVP and $\mathrm{LVdP} / \mathrm{dt}$ with $U \mathrm{cn}$ were more potent and lasted longer than those with CRF. We measured maximum $\mathrm{LVdP} / \mathrm{dt}$ instead of $\mathrm{E}_{\max }$ (an index of contractility) in order to estimate cardiac contractility. Since our experiments were carried out in isovolumetrically contracting heart preparations and the preload and afterload of the left ventricle were kept constant throughout the experiment, the maximum rate of increase in LVP (maximum LVdP/dt) should be an appropriate estimate for cardiac contractility. In practice, it 

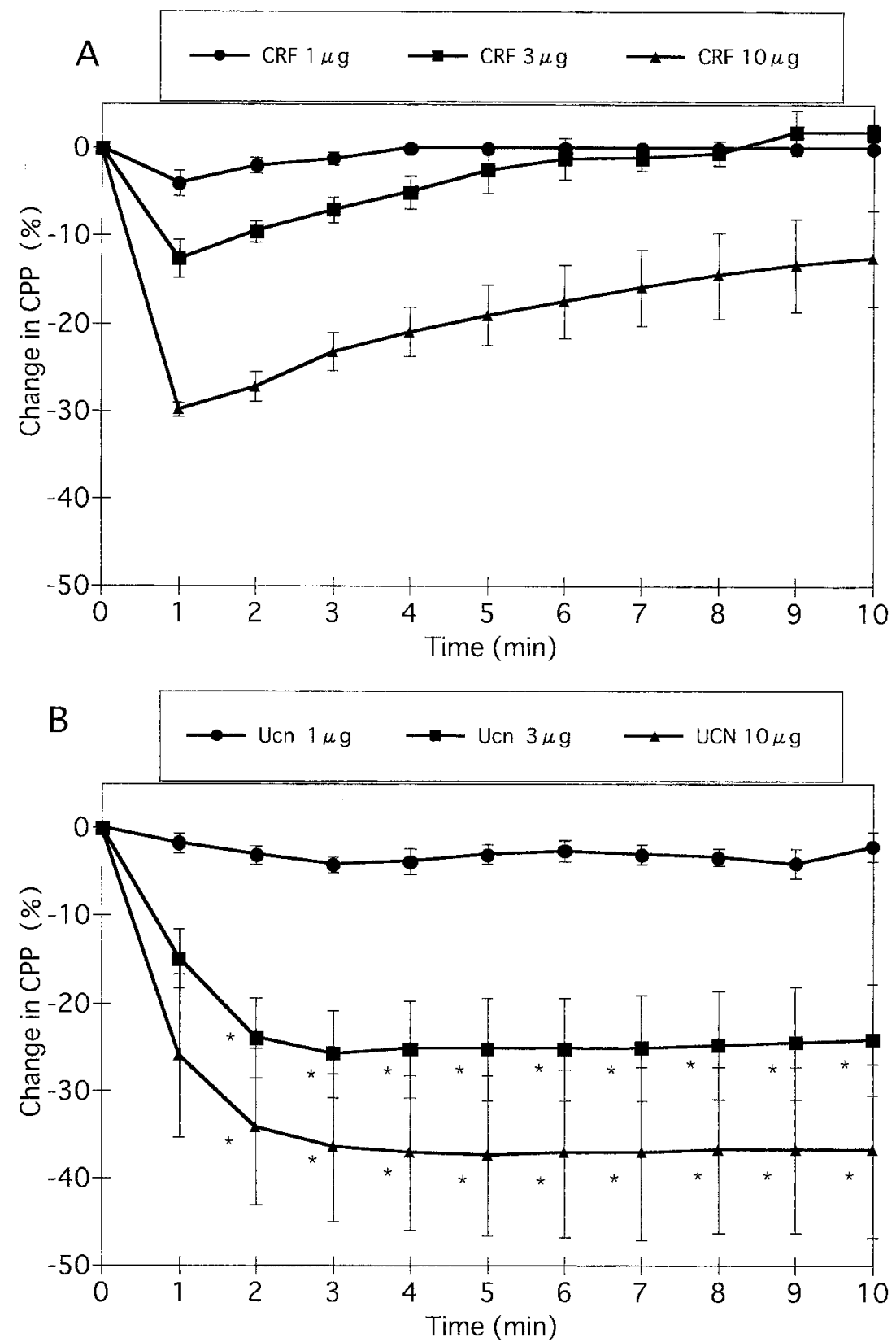

Figure 1 Effects of (A) CRF and (B) Ucn on CPP at $1(n=5), 3(n=5)$ and $10(n=5) \mu \mathrm{g}$. Each point represents the mean \pm S.E.M. ${ }^{*} P<0 \cdot 05$ compared with CRF.

was difficult to measure $\mathrm{E}_{\max }$ every minute since the index requires steady-state LVP recordings at several left ventricle volumes. We therefore focused on the time-course study of the maximum $\mathrm{LVdP} / \mathrm{dt}$ after the injection of the peptides.

CRF receptor antagonist diminished the effects of $U c n$. This result suggests that the cardiac effects of Ucn are mediated by a CRF receptor. Because $\alpha$-helical CRF
9-41 is a CRF receptor antagonist which blocks both CRF-R1 and -R2 we cannot conclude that the cardiovascular effects of Ucn and CRF are exclusively mediated by CRF-R2. However, this study has shown that the vasodilator effect and positive inotropic effect of $U_{c n}$ were more potent and lasted longer than those of CRF. The difference in the effects between Ucn and CRF may be due to the difference in the affinity of the two peptides 


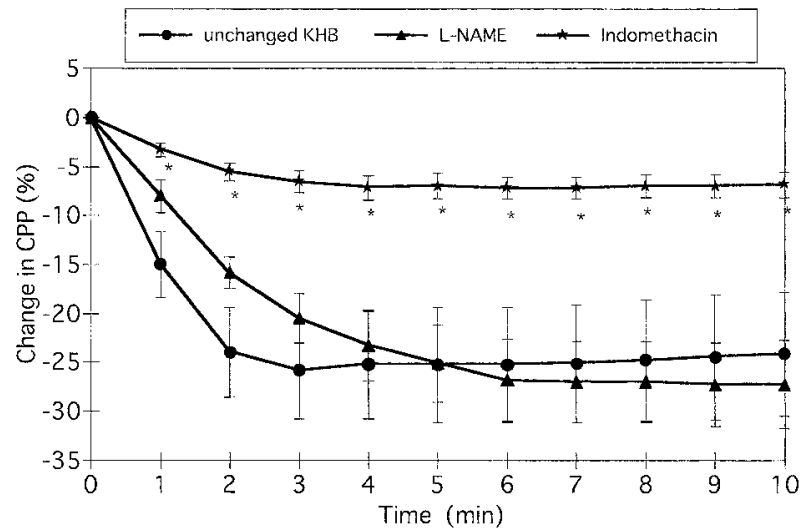

Figure 2 Effects of $U \mathrm{cn}(3 \mu \mathrm{g})$ on CPP in hearts perfused with unchanged $\mathrm{KHB}(n=5), \mathrm{KHB}$ containing $30 \mu \mathrm{M}$ L-NAME $(n=5)$ or $\mathrm{KHB}$ containing $30 \mu \mathrm{M}$ indomethacin $(n=5)$. Each point represents the mean \pm S.E.M. ${ }^{*} P<0 \cdot 05$ compared with hearts perfused with unchanged KHB.

for CRF-R2, as reported (Vaughan et al. 1995). Some investigators have recently generated CRF-R2-deficient mice. It was reported that intravenous administration of Ucn failed to enhance the cardiac contractility of those CRF-R2-deficient mice, in contrast to wild-type mice (Coste et al. 2000). Their results showed that the cardiac effects of Ucn depend on CRF-R2, which supports our findings.

Using in situ hybridization, it has been demonstrated that CRF-R2 was expressed on arterioles of the rat heart (Lovenberg et al. 1995a). This suggests that these receptors were present in endothelial cells and/or smooth muscle cells of the coronary artery. Given that CRF-R2 exists in the smooth muscle cells of coronary arteries, Ucn and
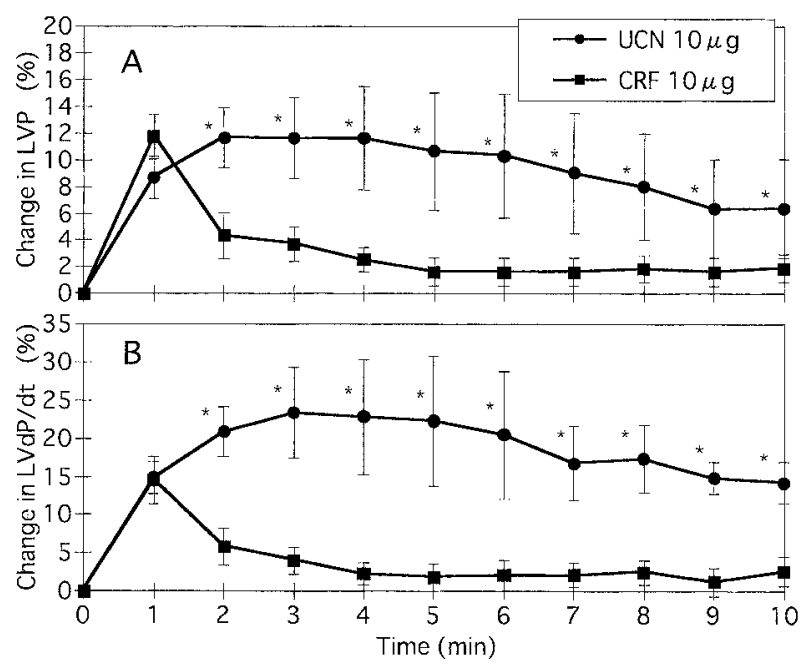

Figure 3 Effects of CRF $(n=4)$ or Ucn $(n=4)$ on (A) LVP and (B) $\mathrm{LVdP} / \mathrm{dt}$ at $10 \mu \mathrm{g}$. Each point represents the mean \pm S.E.M. ${ }^{*} P<0.05$ compared with CRF.

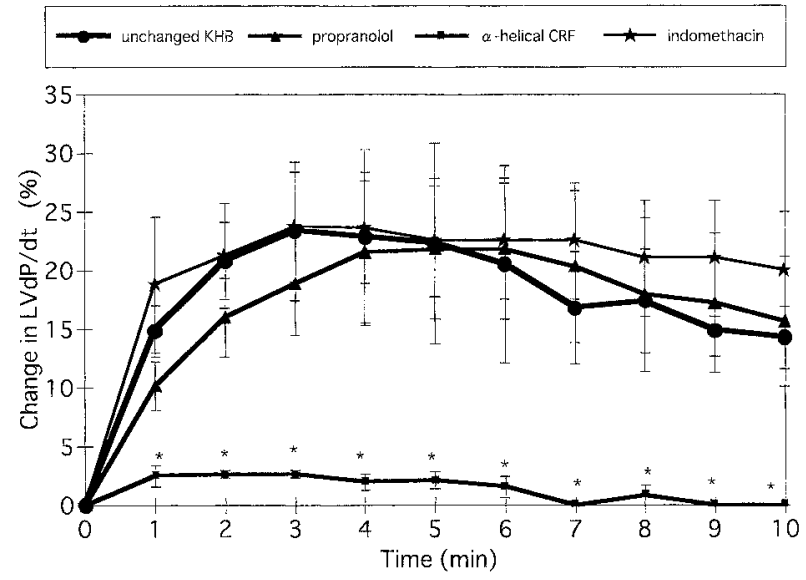

Figure 4 Effects of $\mathrm{Ucn}(10 \mu \mathrm{g})$ on $\mathrm{LVdP} / \mathrm{dt}$ in hearts perfused with unchanged $\mathrm{KHB}(n=4), \mathrm{KHB}$ containing $3 \mu \mathrm{M}$ propranolol $(n=4), \mathrm{KHB}$ containing $30 \mu \mathrm{M}$ indomethacin $(n=5)$ or KHB containing $30 \mathrm{nM} \alpha$-helical CRF 9-41 $(n=4)$. Each point represents the mean \pm S.E.M. ${ }^{*} P<0 \cdot 05$ compared with hearts perfused with unchanged KHB.

CRF could directly relax the smooth muscle cells via CRF-R2 as other vasodilators do via their own receptors.

In this study, indomethacin, a cyclo-oxygenase inhibitor, diminished the Ucn-induced change in CPP. It has also been reported that CRF-induced vasodilation was diminished by indomethacin (Grunt et al. 1993). Since cyclo-oxygenase is a key enzyme for biosynthesis of prostaglandins, our finding implies that prostaglandins, such as prostacyclin, are involved in Ucn-induced coronary vasodilation. It has been reported that prostacyclin was the major prostaglandin released from the isolated rat heart (de Deckere et al. 1977). One explanation for the prostaglandin-induced coronary vasodilator effect of $U_{c n}$ could be that it is due to prostacyclin being released from

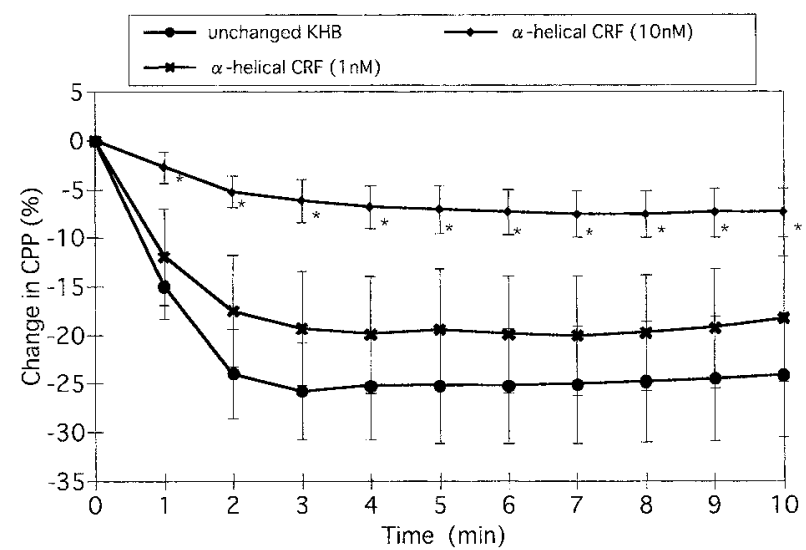

Figure 5 Effects of Ucn ( $3 \mu \mathrm{g})$ on CPP in hearts perfused with unchanged $\mathrm{KHB}(n=5), \mathrm{KHB}$ containing $1 \mathrm{nM}(n=5)$ or $10 \mathrm{nM}$ $(n=5) \alpha$-helical CRF 9-41. Each point represents the mean \pm S.E.M. ${ }^{*} P<0 \cdot 05$ compared with hearts perfused with unchanged KHB. 
the endothelial cells of coronary arteries. However, it was reported that in rat resistance artery preparations CRFinduced relaxation did not depend on endothelial cells (Lei et al. 1993). If the result holds in coronary arteries also, the prostaglandins could be released from cells other than endothelial cells, such as smooth muscle cells of the coronary artery.

Nitric oxide is a potent vasodilator released from endothelial cells. L-NAME did not significantly diminish the vasodilator effect of $\mathrm{U} c \mathrm{n}$ in this study. It is therefore unlikely that Ucn-induced vasodilation was mediated by nitric oxide. Grunt et al. (1993), however, showed that CRF-induced vasodilation was diminished by $\mathrm{N}^{\mathrm{G}}$-nitroL-arginine which inhibits nitric oxide synthase. It is possible that CRF is different from $U c n$ in releasing nitric oxid and that the effect of CRF on the endothelial cells of coronary artery is distinct from that of resistance artery.

Intravenous administration of $U \mathrm{cn}$ in conscious sheep has been found to cause a gradual increase in coronary flow and cardiac contractility which lasted for a few days (Parkes et al. 1997). The slow onset of the cardiac effect of Ucn implies an indirect action of the peptide on cardiomyocytes. In the present study, however, it took only a few minutes to exhibit the cardiac effects of $U \mathrm{cn}$ in the isolated heart. Furthermore, indomethacin diminished the coronary dilator effects of $U \mathrm{cn}$ but did not influence the positive inotropic effects of the peptide. Thus, it is suggested that Ucn increases cardiac contractility via a direct mechanism which is independent of coronary dilation caused by $\mathrm{Ucn}$.

The positive inotropic effect is caused by stimulation of $\beta$-adrenoceptor in cardiomyocytes. Because propranolol, a $\beta$-adrenoceptor antagonist, did not significantly attenuate the inotropic effect of $U_{c n}$, its inotropic effect may not be mediated by $\beta$-adrenoceptor. Catecholamines bind to $\beta$-adrenoceptor in cardiomyocytes and lead to an increase in intracellular levels of cAMP. The positive inotropic effect of catecholamine via $\beta$-adrenoceptor depends on cAMP (Sobel \& Mayer 1973). It has been reported that CRF-R2 mRNA is expressed in murine atrial cardiomyocyte tumor cells and that CRF causes an increase in intracellular levels of cAMP in freshly isolated cardiomyocytes of neonatal rats (Heldwein et al. 1996). This fact suggests that CRF- or Ucn-induced positive inotropic effects may be related to cAMP elevated by the stimulation of CRF-R. In 1998, it was reported that Ucn mRNA is expressed in a rat cardiac myocyte cell line by reverse transcription polymerase chain reaction (Okosi et al. 1998). In that study, Ucn was suggested to be a natural ligand of CRF-R in the heart and to have paracrine effects. It was postulated that the physiological role of $U_{c n}$ might be protection of cardiomyocytes from stress imposed on the cardiovascular system, such as ischemia (Okosi et al. 1998, Brar et al. 1999, 2000). If that is so, the coronary vasodilation and the positive inotropism of $U_{c n}$ would be a relevant response to protect cardio- myocytes from the stress. In addition, it was shown that systemic administration of endotoxin down-regulated CRF-R2 mRNA levels in the heart (Heldwein et al. 1997, Kageyama et al. 2000). These results also suggest a possible contribution of CRF-R2 in the heart to the cardiovascular response to stress.

In summary, this study is the first to present the cardiac effects of $U_{c n}$ in isolated heart preparations. Both Ucn and CRF produced coronary vasodilation and a positive inotropic effect. In addition, the effect of $U_{c n}$ was greater with a longer duration of action than that of CRF. Because a CRF-R antagonist diminished the effects of $\mathrm{Ucn}_{\mathrm{cn}}$, the effects are mediated by CRF-R in the heart. Since the vasodilator effect of Ucn was diminished by indomethacin, Ucn-induced vasodilation may partly depend on prostaglandins.

\section{References}

Brar BK, Stephanou A, Okosi A, Lawrence KM, Knight RA, Marber MS \& Latchman DS 1999 CRH-like peptides protect cardiac myocytes from lethal ischaemic injury. Molecular and Cellular Endocrinology 158 55-63.

Brar BK, Jonassen AK, Stephanou A, Santilli G, Railson J, Knight RA, Yellon DM \& Latchman DS 2000 Urocortin protects against ischemic and reperfusion injury via a MAPK-dependent pathway. Journal of Biological Chemistry 275 8508-8514.

Chang CP, Pearse RVD, O'Connell S \& Rosenfeld MG 1993 Identification of a seven transmembrane helix receptor for corticotropin-releasing factor and sauvagine in mammalian brain. Neuron 11 1187-1195.

Coste SC, Kesterson RA, Heldwein KA, Stevens SL, Heard AD, Hollis JH, Murray SE, Hill JK, Pantely GA, Hohimer AR, Hatton DC, Phillips TJ, Finn DA, Low MJ, Rittenberg MB, Stenzel P \& Stenzel-Poore MP 2000 Abnormal adaptations to stress and impaired cardiovascular function in mice lacking corticotropinreleasing hormone receptor-2. Nature Genetics 24 403-409.

de Deckere EA, Nugteren DH \& Ten Hoor F 1977 Prostacyclin is the major prostaglandin released from the isolated perfused rabbit and rat heart. Nature 268 160-163.

Fisher LA, Rivier J, Rivier C, Spiess J, Vale W \& Brown MR 1982 Corticotropin-releasing factor (CRF): central effects on mean arterial pressure and heart rate in rats. Endocrinology 110 2222-2224.

Fisher LA, Jessen G \& Brown MR 1983 Corticotropin-releasing factor (CRF): mechanism to elevate mean arterial pressure and heart rate. Regulatory Peptides 5 153-161.

Grunt M, Glaser J, Schmidhuber H, Pauschinger P \& Born J 1993 Effects of corticotropin-releasing factor on isolated rat heart activity. American Journal of Physiology 264 H1124-H1129.

Heldwein KA, Redick DL, Rittenberg MB, Claycomb WC \& Stenzel Poore MP 1996 Corticotropin-releasing hormone receptor expression and functional coupling in neonatal cardiac myocytes and AT-1 cells. Endocrinology 137 3631-3639.

Heldwein KA, Duncan JE, Stenzel P, Rittenberg MB \& Stenzel Poore MP 1997 Endotoxin regulates corticotropin-releasing hormone receptor 2 in heart and skeletal muscle. Molecular and Cellular Endocrinology 131 167-172.

Kageyama K, Gaudriault GE, Bradbury MJ \& Vale W 2000 Regulation of corticotropin-releasing factor receptor type 2 beta messenger ribonucleic acid in the rat cardiovascular system by urocortin, glucocorticoids, and cytokines. Endocrinology 141 2285-2293. 
Kishimoto T, Pearse RVN, Lin CR \& Rosenfeld MG 1995 A sauvagine/corticotropin-releasing factor receptor expressed in heart and skeletal muscle. PNAS 92 1108-1112.

Kostich WA, Chen A, Sperle K \& Largent BL 1988 Molecular identification and analysis of a novel human corticotropin-releasing factor (CRF) receptor: the CRF2 gamma receptor. Molecular Endocrinology 12 1077-1085.

Lei S, Richter R, Bienert M \& Mulvany MJ 1993 Relaxing actions of corticotropin-releasing factor on rat resistance arteries. British Journal of Pharmacology 108 941-947.

Lovenberg TW, Chalmers DT, Liu C \& De Souza EB 1995a CRF2 alpha and CRF2 beta receptor mRNAs are differentially distributed between the rat central nervous system and peripheral tissues. Endocrinology 136 4139-4142.

Lovenberg TW, Liaw CW, Grigoriadis DE, Clevenger W, Chalmers DT, De Souza EB \& Oltersdorf T 1995b Cloning and characterization of a functionally distinct corticotropin-releasing factor receptor subtype from rat brain. PNAS 92 836-840.

Okosi A, Brar BK, Chan M, Dsouza L, Smith E, Stephanou A, Latchman DS, Chowdrey HS \& Knight RA 1998 Expression and protective effects of urocortin in cardiac myocytes. Neuropeptides $\mathbf{3 2}$ $167-171$.

Overton JM \& Fisher LA 1991 Differentiated hemodynamic responses to central versus peripheral administration of corticotropin-releasing factor in conscious rats. Journal of the Autonomic Nervous System $\mathbf{3 5}$ $43-51$.

Overton JM, Davis Gorman G \& Fisher LA 1990 Central nervous effects of CRF and angiotensin II on cardiac output in conscious rats. Journal of Applied Physiology 69 788-791.

Parkes DG, Vaughan J, Rivier J, Vale W \& May CN 1997 Cardiac inotropic actions of urocortin in conscious sheep. American Journal of Physiology 272 H2115-H2122.

Perrin M, Donaldson C, Chen R, Blount A, Berggren T, Bilezikjian L, Sawchenko P \& Vale W 1995 Identification of a second corticotropin-releasing factor receptor gene and characterization of a cDNA expressed in heart. PNAS 92 2969-2973.
Potter E, Sutton S, Donaldson C, Chen R, Perrin M, Lewis K, Sawchenko PE \& Vale W 1994 Distribution of corticotropinreleasing factor receptor mRNA expression in the rat brain and pituitary. PNAS 91 8777-8781.

Smith MA, Kling MA, Whitfield HJ, Brandt HA, Demitrack MA, Geracioti TD, Chrousos GP \& Gold PW 1989 Corticotropinreleasing hormone: from endocrinology to psychobiology. Hormone Research 31 66-71.

Sobel BE \& Mayer SE 1973 Cyclic adenosine monophosphate and cardiac contractility. Circulation Research 32 407-414.

Stenzel P, Kesterson R, Yeung W, Cone RD, Rittenberg MB \& Stenzel Poore MP 1995 Identification of a novel murine receptor for corticotropin-releasing hormone expressed in the heart. Molecular Endocrinology 9 637-645.

Vale W, Spiess J, Rivier C \& Rivier J 1981 Characterization of a 41-residue ovine hypothalamic peptide that stimulates secretion of corticotropin and beta-endorphin. Science 213 1394-1397.

Vale W, Rivier C, Brown MR, Spiess J, Koob G, Swanson L, Bilezikjian L, Bloom F \& Rivier J 1983 Chemical and biological characterization of corticotropin releasing factor. Recent Progress in Hormone Research 39 245-270.

Vaughan J, Donaldson C, Bittencourt J, Perrin MH, Lewis K, Sutton S, Chan R, Turnbull AV, Lovejoy D, Rivier C, River J, Sawchenko PE \& Vale W 1995 Urocortin, a mammalian neuropeptide related to fish urotensin I and to corticotropinreleasing factor. Nature 378 287-292.

Wong ML, Licinio J, Pasternak KI \& Gold PW 1994 Localization of corticotropin-releasing hormone $(\mathrm{CRH})$ receptor mRNA in adult rat brain by in situ hybridization histochemistry. Endocrinology 135 $2275-2278$.

Received 22 November 2000

Accepted 14 December 2000 